\title{
Fisnike Pllana \\ The importance of teaching intercultural competencies in an EFL classroom: a case study conducted at the Faculty of Law of a certain University
}

\author{
South East European University, \\ Archbishop Angelarius, No. 11000 Skopje, \\ Republic of Northern Macedonia \\ fp28992@seeu.edu.mk
}

Received on March 31, 2021; accepted on June 10, 2021;
published on June 30, 2021

\begin{abstract}
Intercultural competence is a basic skill that everyone needs to learn, not to mention university students about to enter the workforce. Mastering this skill means tolerating, respecting, understanding and accepting cultural differences. A sample of 68 students was taken from the Faculty of Law at the University of Prishtina "Hasan Prishtina" in Prishtina to fill in a questionnaire regarding the importance of the skill in life and profession. Results show that even though students have some knowledge regarding IC, there is still space for improvements. Teachers have to be professionally trained and the higher institutions should compile more culture-based curricula. The research results were quite surprising and some recommendations were given in order to raise awareness of the significance of this skill.
\end{abstract}

Kew words: intercultural competencies; culture; language learning; awareness.

Information for citation: Fisnike Pllana (2021), "The importance of teaching intercultural competencies in an EFL classroom: a case study conducted at the Faculty of Law of a certain University", Research Result. Pedagogy and Psychology of Education, 7 (2), 74-88, DOI: 10.18413/2313-8971-2021-7-2-0-6.

Introduction. This paper has placed the interest towards the core of intercultural communication, the methods and approaches teachers can use for their classrooms, the significance behind this skill and the data of its usage at the Faculty of Law at the University of Prishtina "Hasan Prishtina". The research will show how language teachers can spread cultural awareness through practicing intercultural communication and how it can be incorporated in lessons without leaving grammar or other important lessons out. Additionally, suggestions of teaching methodologies that can be used in the future are presented in the last part of the paper.

The core motivation of doing a research in this field of study is closely linked with the fact that the implementation of intercultural commu- nication in this fast-changing century is a fundamental need for every human and the sooner the students learn it, the higher the probability of their success. Data shows that the usage of this skill is mainly as a means of building bridges between nations and communities. Theoretically observed, communication comprises the most humane part of each of us, therefore workshops and trainings could serve well as a starting point, following up with lessons in language classes.

Definition of intercultural communication (IC) Regardless of the circumstances of the country in which one is, the possibility of stepping in places that involve different cultures is quite high. The more economically developed a state becomes, the higher the opportunity of meeting different nations and working with 
them follows. How would one communicate, cooperate and become friends with each other, when cultures happen to be different and the diversification can be at various degrees? In life and work, one needs to practice the skill of intercultural communication as a means of connecting with people. Yet the question is: what does this particular skill represent, how should one learn it, and specifically, are the students of the Law Faculty at the University of Prishtina "Hasan Prishtina" acquired with the needed training for it.

Separating the term "intercultural communication (IC)" often also referred to as "crosscultural communication" is taken as a starting point of analysis. The first definition of the word "intercultural", based on the Merriam-Webster dictionary means: "occurring between or involving two or more cultures" ("Intercultural," n.d.). Two other definitions of the word co-exist, however this one serves the purpose of this research. Additionally, the definition of culture needs to be stated: "the way of life, especially the general customs and beliefs, of a particular group of people at a particular time" ("Culture," n.d.). Looking at it from a social perspective, one can argue that not only does culture represent the general customs and beliefs but also the core values of each individual. The difference of personal preferences leads to cultural variety which contributes to complications in human connections. Moving next with the definition of the other part of the term, the word "communication", based on the MerriamWebster dictionary has the following definition: "the act or process of using words, sounds, signs, or behaviors to express or exchange information or to express your ideas, thoughts, feelings, etc., to someone else" ("Communication," n.d.). And since Intercultural communication is part of the term Intercultral competency the definition of the later one is "possession of sufficient knowledge or skill" ("Compenecy", n.d.).

Fundamentally, communication requires effort, but how willing are people to get out of their comfort zones to do it properly is the question. Bennett (1998) states that conflicts arise if people are dealing with cultural differences against their will, but at the same time they do not voluntarily confront themselves with them either. Since primary school, language is taught as an inseparable part of every curriculum and the most appropriate way to achieve cooperation between people is through teaching.

Approaches to Intercultural Competencies. Bennett (1998) lists six steps to understanding cultural differences: denial of difference, defense against difference, minimization of difference, acceptance of difference, adaptation to difference, and integration of difference. This process starts with believing one's own culture is the ultimate reality and ends with the total acceptance towards cultural differences. However, the first three steps are rather concerned with personal changes and the other three with modifications that can be seen from outside. The acceptance-of-difference step requires more than the passive act of understanding, it does rather consist of giving back when decisions are made or feedback is needed (Friedman \& Antal, 2005). The same authors state that the adaptation step is considered to a certain extend manipulative since it represents the built expectation for a certain culture in which people can require particular end products of behavior. This phase may be about adapting behaviors but if performed without critical thought it can lead to judgments and prejudices. The last step of this list is the ultimate understanding of one's own culture and the culture of the others'. Bennett's scale is to a certain extend applicable, however many scholars do think that other approaches work better.

Because culture has a very broad meaning and understanding among people, its approaches change and the components differ based on the chosen perspective to see them. Edward Hall has written many books on anthropology and behavior where culture plays an important role. He came up with a high context and low context way of communication as quoted below:

"A high context (HC) communication or message is one in which most of the information is already in the person, while very little is in the coded, explicit, transmitted part of the message. A low context (LC) communication is just the opposite; i.e., the mass of the infor- 
mation is vested in the explicit code. Twins who have grown up together can and do communicate more economically (HC) than two lawyers in courtroom during trial (LC), a mathematician programming a computer, two politicians drafting legislation, two administrators writing a regulation."

The given concept of low context communication represents the actual state of two people who have not been raised, fed or taught the same. Therefore misunderstandings that occur between people of different cultural backgrounds are initially started because of the presence of the low context communication. What could be done towards solving this problem is strongly related to IC and its practice as an indicator of heading towards the high context communication?

One other aspect of communication is time, more precisely the usage of it, which categorizes some cultures into monochromic and others as polychromic users (Hall, 1979). The monochromic perception of time is when a person deals with one action per time, whereas the polychromic perception is many actions or engagements during a time period (Bluedorn, Kaufman \& Lane, 1992). Samovar, Porter, and McDaniel (2009) state that the polychromic people, cultures as: Africa and South America, are more concerned about the momentum and not that much with schedules, whereas monochromic people, cultures as: North America and Northern Europe, rely their daily performances on time and schedules. Being aware of these differences does save time, effort and misunderstandings between cultures. Notwithstanding the cultural generalizations, there may be exceptions, however knowing in which category a culture falls does help in business, legislate and other important matters.

The Lewis model of time is similar to Halls's perception of time however slight changes do occur. For James Lewis there are three types of cultures: linear-active, multiactive and reactive. The first one corresponds to the monochromic perception of time, which is one action per time, whereas the multi-active type of culture is Hall's polychromic perception of time. Additionally, Lewis adds another category: reactive cultures which include the ones that listen and get the information before talking or giving feedback (Lewis, 2006: 32). These cultures are called reactive, since they give space to the other person to express himself and then come up with a reaction. Fig. 1 represents the cultural division based on the Lewis Model with the countries that model them.

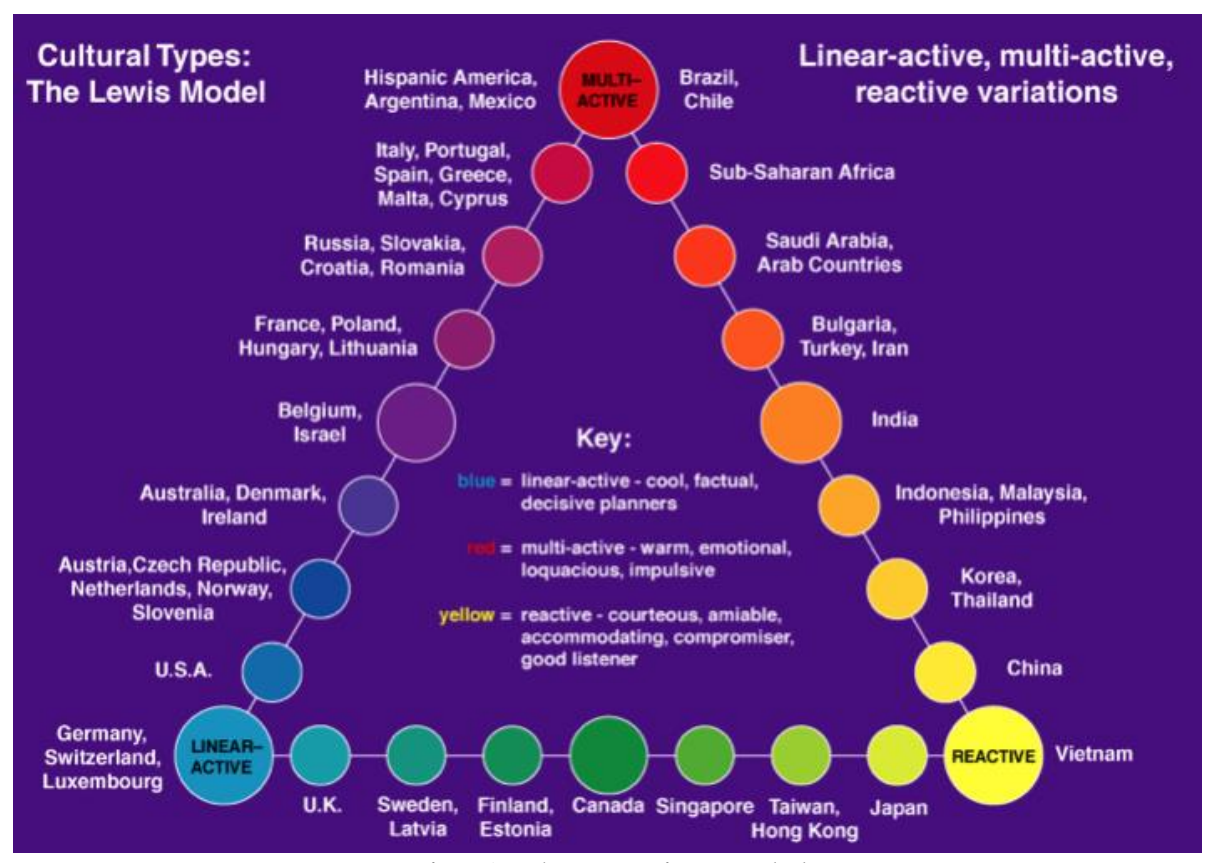

Fig. 1 The Lewis Model 
The significance behind this division of time users could be a starting point of teaching IC since it thoroughly mirrors an internal part of each person and in this case cultures. Explaining the basic concepts of intercultural competencies will make it easier for the students to adapt themselves towards the more complex changes that this skill requires.

Teaching Intercultural Competencies. Understanding the native language's function and culture creates a great opportunity in doing the same with a foreign language. This factor, among others, contributes to the fundamental proficiency and understanding of culture and its usage in another environment. Knowing and respecting the differences among the native and foreign culture makes room for tolerance and positive changes (Crozet et. al., 1999: 21). This is clearly done through theory and practice however one without the other can lead to knowledge but not competence (Bennett, 1998). The teachers' responsibility is to integrate the practices within lessons rather than teaching it as a separate unit or chapter.

Banks (2017), points out the significance of the teachers' and administrators' awareness towards accepting diversity in order to create a safe environment for students. If teachers mirror their own lessons within the classroom, students most likely adapt the behavior and consider it right. A teacher explaining IC and being biased himself with students would create a clash which wouldn't be welcoming for students and would most likely result in failure of teaching IC. The first step would be the above mentioned one, acting and students adapting.

This skill can be taught as a separated subject or maybe integrated in different economic or field specific classes, however, most effectively it would fit into a language class. Crozet, Liddicoat and Bianco's (Crozet, Liddicoat \& Bianco's, 1999: 21) description of the aim of Intercultural Language Teaching stands in attaching the cultural representation with the language teaching, just like teaching the Zen tradition would be appropriate for Japanese and less beneficial for English. Learning a language comes attached with learning some parts of its culture as well as the adequate vocabulary.
To achieve intercultural competence one must not only learn culture but also experience it personally (Bennett, 2009; Perry \& Southwell, 2011). Ideally, language students would be sent abroad for a time period in order to experience interculturality themselves, however because this is not always possible, the teacher has to work on making the classroom a stimulated multicultural room. Learning in a classroom has to be experimental and change has to be in the center of it; through change there is progress (Byram \& Feng, 2005). Schenker's (Schenker's, 2012) study explains the benefit of exchanging e-mail transcripts between her American students and German students as a form of teaching intercultural competence. Not only were they giving feedback to each other, they saw a different point of view of things through writing. This and many other methods lead to direct but virtual encounter of students of different cultures, nations and environments which can serve the teachers but mostly the students.

Literature review. The act of communicating between people from different cultures is considered intercultural communication (Sun, 2013). Whether this communication is not offensive and successful is all based on the knowledge of this skill at the right moment. Every profession includes human contact and no matter if the nationalities are alike or different, people need to know some basic behaviors in order to comprehend each other. The burden and luck to teach this skill falls on the teachers and the most practical class is: the foreign language class. Teaching English as a foreign language embodies the responsibility of teaching about a globalized world and cultural acceptance; whether teachers fulfill it or not is another matter.

$\mathrm{Xu}(\mathrm{Xu}, 2017)$, in a study done with an online writing class has encountered some components of metacultural writing competence. The first component is: people may use the same word in a language to express something very different when translated in their native languages, i.e. the word 'love' would be used by Chinese to describe the love for a city and a different word for the love towards their 
parents. Whereas English uses the same word for every kind of affection towards something. The second component is the explanation ability, which is the ability to explain why things work in a culture the way they do. The third component of this study is the negotiation ability which is the capacity of different nations to negotiate intercultural concepts. The three explained components can be taught in a writing class or during writing assignments which are an inseparable part of each language class while assessing them in a very practical way.

The implementation of the native culture in the process of teaching intercultural competencies is still very debatable. The Chinese Ministry of Education has published the curriculum for teaching English in 2000, including the explanations of the native culture as an inseparable part of teaching foreign cultures, however it has not been into practice fully ( $\mathrm{Ji}$ nan, 2015). Usually, if there is focus on culture, it is mostly on the target language culture and not in the native. The present curriculum of the Ministry of Education, Science and Technology in Kosovo for the English classes in high schools does include intercultural competencies. A very long list of IC is presented on the official webpage and they are required to be fulfilled by every language teacher (Official MEST webpage). The fourth section of the skills that teachers have to teach is titled "English in the world" with the subsections: comparison of languages and cultures, interactions with the representatives of the target language and the use of the target language for leisure and personal enrichment. The given curriculum is very rich on intercultural competencies however if it would have been implemented the way it is according to law, the students that finish high school would be culturally competent.

The University of Prishtina "Hasan Prishtina" on the other hand does not have a particular curriculum for all language classes but each Faculty has their own. Most of the curricula are adjusted to the needs of the particular field, nevertheless, the language departments do teach the cultural components in multiple classes during the overall study program. Curran (Curran, 1993), has written a book
"French for Lawyers" for students who are leaning French but study Law. Similar adjustments to the needs of the students are crucial, since learning the terminology of the field one is studying in is very practical towards developing other skills, therefore teachers need to be provided with English for Specific Purposes (ESP) materials. Curran (1993) evaluates his students not only on language skills but also cultural and historical events concerning the French language, this way combining the facts with the proper way of uttering them.

Dicey (Dicey, 1900) claims that teaching English law is not art but a since, highlighting the importance of learning this skill with law reports and not books. Without dealing with legal matters and thoroughly analyzing them, it is hard for a language teacher to know each term and process. Hajdu and Domonyi (Hajdu \& Domonyi, 2019), state that the English language taught in business or translation classes has to be intertwined with IC since no job can be done rightly if this skill is not thoroughly used. Besides the language skills, teachers have to be prepared to stand in front of every kind of audience. Each field of study requires at least the basic knowledge of the terms and the process regarding that profession. Under these conditions, teachers have to be prepared and, if possible, professionally advised before entering a new field of study; this could be possible through workshops or even special field trainings.

The importance of culture in life and profession is incomparable. Each person does know basics of culture however very often insults happen without knowing how or why it came to them. Humans from their nature have to readjust their behaviors based on the environment and the company they are in. The usage of IC is especially needed in diplomatic matters and connections. Its power lays in the capacity to change and shape the community with its perspectives and rules (Katrandzhiev, 2004: 89). Despite the fact that this skill is teachable and important, the implementation is always linked to: the teachers' belief whether interculturality and language fit together and their ability to teach and asses it (Sercu, 2005: 165). The lack of professional trainings and a 
lot of unknown components add to the incapability of teaching IC.

In a study done in a U.S. university for academic writing the results show that while students were talking with their multicultural counterparts, they were not realizing the changes of behavior they were making in order to be understood clearly (Chen, 2018). This, among others, can be considered a proof that just like every other thing that is learned, firstly it is unseen, but later on the changes are more obvious. Likewise, students do not see their own progress immediately but after a period of time.

Norhafezah, Joyce and Amrita (Norhafezah, Joyce \& Amrita, 2019), on their study of IC in the workplace suggest that without experiments and direct exposure of students towards cultural matters they cannot advance in this skill. Therefore, the students were assigned to observe global workplaces for $20 \mathrm{~h}$ a week for 7 weeks. The students were able to identify: the enhancement of their communication skills, a comparison of work ethics of different cultures, challenges certain cultures had during their work time and their own opinions towards intercultural communication. When students are faced with a workplace, multiple components occur, and sooner or later they will enter the work world. If there is no possibility of exercising IC during studies, they certainly will in their workplace. It occurs that the accent one is speaking in can cause misunderstandings while working, and co-workers have to adjust their way of speaking due to the needs of others (Evans, Suklun \& Nunn, 2017). Variations of speaking is the second thing a person is dealt with when seeing someone. After the body language, the way one speaks gives a tone to the overall mood of the conversation. One needs not to forget that communication resolves around changes and progress, therefore a small daily improvement will lead to a more cultural aware individual.

A study conducted about the power relationship between workers and the ways this could interfere in their daily lives shows that tension is easily created when requests or orders are made, therefore the right face-work approach would deflect from problematic mat- ters ( $\mathrm{Li}, 2016)$. The workplace is always unpredictable therefore it would be very good if students would be prepared to withstand difficult situations and act using emotional intelligence.

Emotional Intelligence is referred to the ability of managing one's own emotions in different environments ("Emotional Intelligence", n.d.). This means that even when emotions are triggered by external forces, one has to be prepared to act rightly. Cultural clashes can cause a lot of emotional baggage and therefore the combination of these skills is the road to successful communication. Business students have to be prepared to work and function in a foreign culture even if they are not welcomed by the later (Fall, Kelly, MacDonald, Primm \& Holmes, 2013). Ideally, everyone would be treated equally, however uncomfortable situations will be always part of the daily and work life. Therefore, teaching acceptance to business, law, architecture and all kinds of students is the task of every and not only language teachers.

Research methodology. The methodology section of this paper consists of an explanation of how the research is done. The selected participants, the method of data collection from various institutions along with the methods and activities that were used during the research will be explained in the section below.

\section{Aims and Objectives}

-This study aims to thoroughly explain the importance of teaching intercultural communication.

-The data collected by the Law students will help in creating an idea of what needs to be improved and how.

This research aims to identify the missing methodologies in an English Classroom regarding Intercultural Competencies. It is of the utmost importance to teach culture along with language since the right terminology is strongly linked with a cultured behavior. Until recently only the United States have been related with the term Melting Pot "a place where a variety of races, cultures, or individuals assimilate into a cohesive whole", however Europe has been moving in the same direction for some time now ("melting pot," n.d.). This is a very strong reason for moving towards more modern methodologies in language classrooms in order to be 
up to date with the world and build healthier cooperation.

Materials. The used materials for this paper are various scientific papers, books regarding IC and the book used by the Law Students of the University of Prishtina "Hasan Prishtina": "English for Lawyers" - Dunja M. Vićan, Zlata Pavić and Branko Smerdel 2005, Zagreb, Croatia.

Participants. The sample of this research consist of sixty-eight students from the Faculty of Law due to the tendency of them being involved in legal matters which may include different nationalities. An additional reason is because people of this profession will defend various cultures in court and will deal with legal matters daily therefore, they need to have a basic understanding of the impact that culture has in a person. The knowledge and awareness of intercultural competencies for this particular profession is of the upmost importance.

Instruments. As a means of collecting data, a questionnaire was used. Data was collected through the questionnaire and then analyzed through percentages and coding the openended question. The benefit of a questionnaire is that one can collect wanted data with a large sample quite easily (Jones, Baxter \& Khanduja, 2013). The questionnaires were distributed online due to the inability of doing it physically as a result of the happenings in the world including the world pandemic. A Google Form has been created and all answers were successfully taken. The questionnaire consists of 15 questions: 2 demographic questions, 12 questions with options and an additional openended question.

The questionnaire was created to get a clear view of how informed students of the Faculty of Law at the University of Prishtina "Hasan Prishtina" were for the significance of intercultural communication. Moreover, how much does the University invest in them in order to develop in this field and if it really is a lack of interest from students or rather materials and opportunities.

Procedure. This research has used a mixed method approach, with sixty-eight faculty students of the University of Prishtina "Ha- san Prishtina". The combination of the qualitative and quantitative methods of research is recognized as the mixed method (AramoImmonen, 2013). Additional information has been collected by the institutions regarding curricula and trainings related to the field of study. After the results of the questionnaires a comparison was done to the curriculum of the English classes in the high schools in order to see whether they were prepared for the English classes at the University. The curriculum from the Ministry of Education, Science and Technology have been analyzedon the basis of the cultural competency elements and a conclusion was formed.

Results and data analysis. The data analysis section of this paper is presented in two sections. The first section includes the results the questions from the questionnaire, the second section is the analysis of the book used by the students of the Law Faculty and the interpretation of the results. The book "English for Lawyers" written by Dunja M. Vićan, Zlata Pavić and Branko Smerdel (Dunja M. Vićan, Zlata Pavić \& Branko Smerdel, 2005) in Zagreb and the significance behind analyzing the book lies in understanding why the students have shown the final results.

Results from the questionnaire. The majority of the answered questionnaires are from Female $(76.5 \%)$ students of this faculty, where the total number of participants was 68 , where $25(36.8 \%)$ where first year students, 14 (20.6\%) second year students, 19 (27.9\%) third year students and $10(14.7 \%)$ fourth year students. The availability of first year students was much higher than the fourth-year students. The answers to question 3 show that the majority of students strongly believe that English will serve their future however 4 (5.9\%) responded that they strongly disagree with the statement. When the students were asked whether the knowledge of the target language is important the majority agreed and only $1(1.5 \%)$ student disagreed. The collected answers are to a certain extend controversial since all options got chosen, however the detailed analysis of why the results are this way will be explained in the data analysis section of this paper. 
In the given statement: I am familiar with some rules of behavior in some European countries, the students have shown the same results for the often and sometimes option with a percentage of 39.7 ( 27 students). Only one student has chosen the option never leaving it with a 1.5 percentage. The answers to question 7 have a varied set of answers however with a tendency of rather moving towards the positive answer of always, often and sometimes. Only $22.1 \%$ have answered with rarely and never. The collected answers to question 8 show that the majority of students agree with the stereotype that Albanians are prone to being trustworthy with an opposing thought as well of $13.2 \%$. The answers to question 9 show a higher percentage in the options sometimes and rarely, to a certain extend similar with question 8 with which it had a linked meaning, however the option never is more strongly emphasized in this question compared to the $8^{\text {th }}$.

The answers to question 10 vary from each other however a part of the students answered that they would not know how to behave in court hearings with European citizens nevertheless $61.7 \%$ believe they would know.
Question 11 was constructed in the purposeful way to test the students and the option Always has taken the most votes from the students which means: the majority of students support a behavior which is simultaneous besides the nationality difference. Only $10.3 \%$ of students state that they would rather not behave in the same way.

This question had an additional open-ended question asking why the students gave the abovementioned answers. These answers where coded and the findings are presented below.

Fig. 2 is a clear portrayal of the coded answers, showing that $43.9 \%$ of the students believe that no matter who is on the table, they would speak in the same way to each of them, relating this to equality and human rights. Some students $(10.6 \%)$ have answered that using English with people from other countries is the key to being understood but have not given the precise answer to the asked question. Moreover, only $9 \%$ have stated that no matter the differences between nationalities they would try to be neutral and act with respect according to the circumstances.

\title{
Open-ended question: WHY?
}

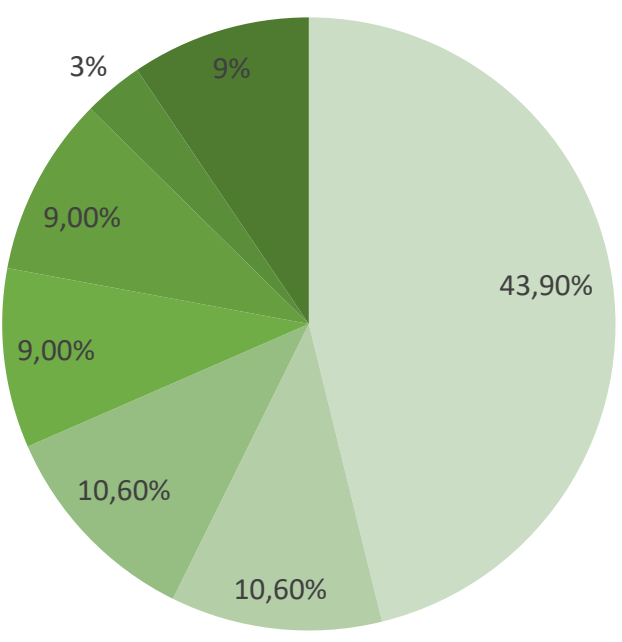

\author{
Same - Equality \\ English as an International \\ Language \\ Conforming to others' differences \\ Neutral - Respectful \\ Others should conform me \\ Acknowledgement of cultural \\ differences \\ - Same Behaviour - No given reason
}

Fig. 2 Students' answers to Question 11.1

A small number of students $(9 \%)$ have stated that they would wait for the response of the others as a guide to how to treat them. If the other people would not be interested in the student's culture the latest would not be either in his/hers. Since humans have to adapt to each 
other for collaboration and life in general, $10.6 \%$ of the answers were pro to act in a conforming way always based on the surroundings.

Moreover, 3\% of students have not understood the question and another 9\% have stated that they would speak in the same way with each different nationality but have not attached any reason to it. One of the smallest percentages (3) was taken from the students that answered that they would behave differently due to cultural differences, which is the most correct answer.

The answers to question 12 show that the majority $(95.6 \%)$ consider using the international language (English) when they don't know other languages meaning that they wouldn't see it as a barrier but rather as a solution. The results of the last question where positive since the majority of students voted that they would like to learn more about other cultures for personal and professional use. Only $1(1.5 \%)$ student strongly disagreed with this statement.

Data analysis. Evaluating the intercultural competencies has been the main goal of this research. Since these skills do affect the lives of the students internally, they have to be taught as a practical tool for the future. Different cultures are living now nearer each other than ever before and language classes "have to be more complex and rich" (Sercu, 2005). The interpretation of the research results will follow in this chapter along with a few suggestions regarding the teaching of the intercultural competence skill.

The need for intercultural competencies in Europe, which is multiethnic, is still present and has to be worked upon (Pappenheim, 2006: 69). Serving as an international language, the English language has become a bridge between cultures and nations, and since the study is focused on teaching IC through this language, questions were constructed in the same direction. The questionnaire comprises a question of whether this language is a crucial component to the students' future, and the vast part $(67.7 \%)$ of the students have agreed. Most of the world's scientific works are published in English and it is most studied second language in the world (Altbach, 2007). Its popularity has no doubt therefore the students have been quite aware of this fact, linking it to the concept of globalization which is getting closer at a faster pace each day.

Some interesting results have occurred during the analysis of the questionnaire answers of this study. The responses of whether American/English culture is taught by the language teacher at the Faculty of Law has got controversial results since each of the Likert scale options have reached a lot of votes. Nevertheless, the option "sometimes" has got the highest percentage (33.80). With the given answers, students show a lack of certainty of what has been explained during the English classes, this could be either for the fact that they missed the class or the lessons haven't been culture centered.

Likewise, question 7 , is also debatable from the answers since this one is related to the knowledge of intercultural communication taken from the language classes and the results show a variety of answers applying to all options. The biggest question mark in these results is set to the point of why the perception of the students are so different when they have all gone through the same curriculum of English classes in the Faculty of Law. Therefore, an analysis of the curriculum followed and based on the English language book, cultural issues have been mentioned only in reading comprehension exercises. The exercises were mostly grammar based and the book in itself does not comprise enough cultural issues. The combination of missing classes and the curriculum that is not fully compatible with IC confused the students and caused the high gap between these answers.

"English for Lawyers" written by Dunja M. Vićan, Zlata Pavić and Branko Smerdel 2005 in Zagreb, Croatia, is an ESP (English for Specific Purposes) based book. The content of it is mainly a description of the terminology which is needed in the law profession and the processes that the law students need to be aware of. English as a foreign language is taught only two semesters, two classes per week, and the curriculum is quite overloaded 
with the terms; intercultural competence could only be touched as a theme but not covered fully. However, classes could be more culture oriented where students learn law and culture in a parallel approach.

The answers to question 10 show a high level of confidence from the students since most of them (38.20\%) have stated that they would know how to behave correctly in a court session with European, however the same have pointed out that they would behave in a same manner (57.40) with different nationalities when dining with them. These answers, again, show that the students have misperceived the concept of IC and have wrongly judged their cultural competencies. The results are disputable due to the lack of cultural material they have had during their studies and the lack of cultural clash experiences.

The results of the open-ended question show that the majority of students have looked at the issue of whether the communication should be the same with different nationalities as a human rights-based question. $43.9 \%$ of them have given various reasons of why humans should be treated the same even though the question had a completely different direction. Only 3\% of the open-ended answers have a strong understanding of why the communication between different cultures should be different. These answers gave a short but thorough comprehension that the difference in communication is critical to moving a step forward and not cross any cultural barrier. Yet, 9\% of the students have chosen to answer in a defense mode, linking the example of dinning with different nationalities that the latest should conform them and not vice-versa. Linked with the fact that these students study law, the concept of equality has been very much misunderstood and this mirrors a major lack of intercultural competencies. It is of the utmost importance for these students to learn and master this skill. Culture is the key to diplomat's success since the right usage of it turns the audience into followers (Katrandzhiev, 2004: 89). Likewise, it can turn law representatives into sympathized people by the overall community and make them successful in their work.
Some scores taken from the questions state that the students are aware of the misunderstandings between cultures because of cultural differences, yet opposing with the overall analysis of their competencies. The law students do not show high understanding of IC and its importance however they show readiness to learn it for their personal and professional use.

After the analysis of the results of the questionnaires, a few suggestions will be presented concerning methodologies of teaching Intercultural competencies:

\section{a) Teaching IC through literature}

Reading is not only pleasing for a person; it is very productive in many aspects as well. As language teachers, we are all faced with some resistance from our students when it comes to assigning certain long readings, however, it can serve as a gate towards a deeper cultural understanding. Burwitz-Melzer (2001), has conducted a research regarding IC with a group of students in Germany. Through a text for Mexican migrant workers, the students were faced with cultural blocks, prejudices, misunderstandings and within this process they were testing their own attitudes towards the situation. It is not necessary for a teacher to only follow the class book, with a bit of creativity, extra worksheets and materials, all skills can be covered during a semester. With a reading task, a teacher can experiment as much as he/she wants, since it gives the opportunity to assign various tasks, such as:

-comment the text with your own words,

-identify the cultural components of the text,

-highlight the prejudices in the text,

-write an essay concerning the same cultural problems,

-describe the feelings of the characters, etc.

This method would be very productive in every language class since through readingcomprehension tasks, students are faced with various skills at the same time and they are especially exposed to cultural differences.

Some students consider literature and reading as the most entertaining part of the 
class (Narančić-Kovać \& Kaltenbacher, 2006). Heading into a task with a good mood brings likewise results. Henceforth, students will be relaxed and will gain knowledge in the process of reading what they like. In these scenarios, the teacher's task is to comment the reading on multiple perspectives, through active discussions and games which will entertain and teach the students.

\section{b) Teaching IC through art and history}

Including the culture, history, art and features of the target country in the language teaching classroom enforces the importance and understanding of the language (Kramsch, 2013). History and the core values of a country are a clear representation of its nation. Students have to differentiate and accept why cultures act the way they do. Chinese people tend to visit their relatives without informing them beforehand however western cultures usually set an appointment (Sun, 2013: 373). The way of living is connected to art, history and especially language usage since it is a mirror of a major part of a person, therefore teaching a foreign language is inseparable to other components. Intertwining these minor details with culture does open multiple world perspectives even if students are not there physically.

Through teaching history events, teachers can explain grammar tenses and exercise in a very practical way. Using this method will not put either skill on the spotlight for students and will make them feel as if they are learning only one. The accumulation of cultural competencies will happen continuously and changes will be long-term.

c) Teaching IC through project-based learning

We learn best by doing - this is very true in every aspect of life. Project-based learning is "learning by doing", and is a very preferable technique of language learning (Tseng \& Yeh, 2019). This technique focuses mostly on the process that students go through while learning something new. A theme has to be set by the teacher in accordance with the students so the later will work on it for a certain period of time (usually a semester). This way a lot of skills can be integrated with multiple assignments and a final summarized project. Since Kosovo has $5 \%$ minority population, an interesting assignment would be to explore the ways of living, schooling and working of these cultures. Students would be directly faced with the differences and challenges IC brings with it and learn more outside of class than within.

d) Foreign language teachers should mirror intercultural competencies

Only when teachers see the learning and teaching process of the foreign language as intercultural, will they be able to reflect and embed the skill to their students (Sercu, 2005: 181). Teachers have to be taught themselves first in order to teach and reflect it. However, rarely do we experience teachers who have been educated for intercultural competencies.

The professor who enters the class in a positive and accepting manner, treating everyone fairly and rightly will be respected and looked upon. If the professor is a reflection of what he/she expects from students it is easier for them to follow. Therefore, besides the curriculum and explanations, the attitude of the professor towards students will teach the later a lot about culture and behavior.

\section{e) Assessing IC}

Assessing cultural knowledge is not as simple and straight forward as assessing a test. Since intercultural competencies include a number of values which have to be measured, the best and most practical way would be using formative assessment. Formative assessment is the continuous assessment of students during a semester; this way students get assignments more often but smaller and teachers have the opportunity to change the instructions based on the students understanding (Boston, 2002). Using essays, presentations, project-based learning will lead to a cultural aware classroom and a successful one, and this way teachers would have a scheme on how to evaluate students. If teachers get uncreative on what methodologies to use, books and the internet are the vastest sources of ideas and experiments which will lead to a very bright full classroom.

Conclusion. Hypothetically, if there were a world without cultural competencies, would we be able to co-exist? This fundamental ques- 
tion has to be asked since only if we think about the non-existence of this skill do, we really see the benefits it brings along. Theoretically, this world managed to work even when humans were not able to exchange goods with foreigners but whether it was practical is debatable. The human species did indeed evolve and successfully created a bond that has showed priceless benefits in the world in the era which is moving towards academic needs for communication and cooperation.

Intercultural competence is considered to be the ability to behave and communicate in a correct way when being with people from different cultural backgrounds. It is the foundation of each human being. Halls' (Halls', 1976) explanation of the high and the low context are a clear mirror of how language functions and where the barriers are more likely to be set. The significance lies on understanding the time concept used by cultures as well. Some nations fall into the category of monochromic time users and others into polychromic. If people's timing is not respected during life and business, the likelihood for conflicts to arise is quite high and the communicative parties will not be satisfied with each other, therefore no cooperation will happen at any stage.

Students have to be taught skills like these in school and college. This study was mainly focused on the knowledge law students at the University of Prishtina "Hasan Prishtina" have on intercultural competencies. A questionnaire was used as a tool of gathering the data for the study with a sample of 68 students. Various questions were set to identify the awareness of this skill and the level on which has been taught. After thorough analysis, the results show that the law students are not taught IC and do have little knowledge regarding the concepts of it. The study has been contradicting in the part where the analysis was concentrated in the past knowledge these students have brought to the classroom. The analyzed curriculum of the high schools shows a high level of Intercultural competencies. Not only have the teachers had the duty to teach this skill, the books where filled with exercises and chapters regarding IC. It is acceptable that students will forget through the passing of time, however IC falls into the category of skills that is deeply integrated in the human psychology and needs to be used while we talk and walk. Even if they were not aware of the term Intercultural communication, these students had to have basic knowledge of cultural differences before entering University.

An interesting finding was the humanrights point of view of the law students. Questions that were constructed with the focus on finding the cultural awareness level were treated as human rights questions. When asked if the treatment of people would be different based on their nationality, a vast number of answers were against it. In the open-ended question, the reasons were mainly that each human has the same rights and has to be treated the same. The profession in which they will soon be finding themselves does require a high level of tolerance and IC is the skill that would be easily incorporated and needed.

All the questions were successfully answered during the study and the hypothesis of the paper were also almost fulfilled. Three hypotheses have resulted to be correct, however the one which states, that teachers would be ready to use IC if they would be trained on it, was not due to the limited resources of finding out. Students do unfortunately lack the sufficient content to be culturally aware and gaining the skill through experience is also available only for a small number of students. The analyzed curriculum does not fulfill the IC needs and teaching the skill does not exclude other important skills it actually reinforces them.

Few suggestions were given on how to implement this skill into the language classrooms including teaching IC through: literature, art and history, project-based learning and the reminder that foreign language teachers should mirror intercultural competencies themselves before teaching them. If the class needs to be successful, the teacher has to mirror what he/she is trying to teach. Language classes are considered the best place to integrate IC since through learning language one learns the function of it, the structure and the right usage. It is the teachers' duty to try and teach this skill us- 
ing experimental methodologies however, an additional method of learning IC would be sending students for a semester abroad in order for them to face cultural differences and fundamentally learn them. Assigning books, projects, and drawings touches upon a lot of spheres and creates multiple skill learning at the same time, and all these wonderful things can be learned in a language classroom.

Limitations. During the compilation of this paper, only a few things haven't proceeded the way they were planned. The questionnaire was planned to be distributed physically and the sample to be larger, however due to the inability of doing so, the questionnaire was electronic and the sample smaller. The Ministry of Education, Science and Technology has got only the curricula of the high schools of the country and not a standardized one for the University. Each Faculty has got a separate curriculum but no data was found of a generalized one which has to be followed, this way each language professor decides what is best for the classroom without having a state template to follow.

\section{References}

Altbach, P. (2007), The Imperial Tongue: English as the Dominating Academic Language. Economic and political weekly 42 (36), 3608-3611. DOI: $10.2307 / 40276356$.

Banks, J.A. (2017), An Introduction tom Multicultural Education (6 th edition). Retrieved from https: $/ /$ www.pearsonhighered.com/assets/preface/0/1/3/4/0 134802403.pdf (Accessed 12 February 2021).

Bennett, M.J. (2009), Defining, measuring, and facilitating intercultural learning: a conceptual introduction to the Intercultural Education double supplement. Intercultural Education, 20 (sup1), 113. DOI: $10.1080 / 14675980903370763$.

Bennett, Milton. J. (1998), Intercultural communication: A current perspective. In Milton J. Bennett (Ed.), Basic concepts of intercultural communication: Selected readings. Yarmouth, ME: Intercultural Press. Retrieved from https://pdfs.semanticscholar.org/ea2e/a5b092b3094 6b4717595dba81ffb0a24d9ff.pdf (Accessed 07 March 2021).

Bluedorn, A.C., Kaufman, C.F. and Lane, P.M. (1992), How many things do you like to do at once? An introduction to monochronic and poly- chronic time. Academy of Management Perspectives, 6(4), 17-26. DOI:10.5465/ame.1992.4274453.

Boston, C. (2002), The concept of formative assessment. Practical assessment, research, and evaluation, $8(9)$. DOI: https://doi.org/10.7275/kmcq-dj31 (Accessed 03 February 2021).

Burwitz-Melzer, E. (2001), Teaching Intercultural communicative competence through Literature. In Byram, M., Nichols, A \& Stevens, D. (Eds.), Developing Intercultural Competence in Practice (pp. 29-44). United Kingdom. Multilingual Matters. Retrieved from: https://books.google.com/books?id=OWG8V1XIhl $\mathrm{oC} \&$ printse $=$ frontcover $\# \mathrm{v}=$ onepage $\& \mathrm{q} \& \mathrm{f}=$ false (Accessed 20 March 2021).

Cambridge Dictionary (n.d.). (2020), Culture. In Cambridge-Dictionary.com dictionary. Retrieved May 27, from https: // dictionary.cambridge.org/dictionary/english/culture (Accessed 13 March 2021).

Chen, T. (2018), "But I learn more bad grammars when I write to my classmates": Acquiring academic literacies in a multicultural writing class. Journal of International Students, 2166-3750. DOI 10.5281/zenodo.1249047.

Crozet, C., Liddicoat, A.J. and Bianco, J.L. (1999), Introduction. In Crozet, C., Liddicoat, A.J., Bianco, J.L (Eds.). Striving for the third place: Intercultural Competence: from Language Policy to Language Education. Melbourne, Language Australia.

Curran, V. (1993), Developing and teaching a foreign-language course for law students. Journal of Legal Education, 43(4), 598-605. Retrieved from https://www.jstor.org/stable/42898164?read-

now $=1 \&$ seq=1\#page_scan_tab_contents (Accessed 27 March 2021).

Dicey, A.V. (1900), The teaching of English law at Harvard. Harvard Law Review, 13(5), 422440. DOI 10.2307/1323359.

Evans, A., Suklun, H. and Nunn, S. (2017), Workplace diversity and intercultural communication: A phenomenological study. Cogent Business \& Management, 4(1). Retrieved from https: DOI.org/10.1080/23311975.2017.1408943.

Fall, L.T., Kelly, S., MacDonald, P., Primm, C. and Holmes, W. (2013), Intercultural communication apprehension and emotional intelligence in higher education: Preparing business students for career success. Business Communication Quarterly, 76(4), 412-426. DOI: 10.1177/1080569913501861.

Hajdu, Z. and Domonyi, R. (2019), Integrating the language aspects of intercultural competen- 
cies into language for specific purposes programmes. In Goria, C., Guetta, L., Hughes, N., Reisenleutner, S., Speicher, O. (Eds.). Professional competencies in language learning and teaching. (pp. 65-77). United Kingdom: Researchpublishint.net.

Information for the English language curriculum. Retrieved from: https://masht.rksgov.net/planprogramet-1

Jinan, J. (2015), Absence of national culture in foreign language teaching and intercultural communication competence training of college students in china frontier minority areas. English Lan$\begin{array}{lll}\text { guage } & \text { Teaching, } & \text { 52-56. }\end{array}$ DOI:10.5539/elt.v8n4p52.

Katrandzhiev, V. (2004), Cultural content on the websites of diplomatic systems. In Slavik, H. (Edit.). Intercultural communication and diplomacy. (pp. 89-109) Malta and Geneva. Diplofoundation. Retrieved from https://books.google.com/books?id=5-

k $7 \mathrm{nEx} 2 \mathrm{a}$ YC \& printsec $=$ frontcover $\# \mathrm{v}=$ onepage $\& \mathrm{q}$ $\& \mathrm{f}=$ false (Accessed 01 February2021).

Kramsch, C. (2013), Culture in foreign language teaching. Iranian Journal of Language Teaching Research, 1(1), p. 57-78. Retrieved from: https://files.eric.ed.gov/fulltext/EJ1127430.pdf (Accessed 01 February2021).

Li, S.S.B. (2016), Bridging the Micro- and Macro-levels: Rapport Management in Intercultural Workplaces. Global Studies Journal, 9(3), 31-41. https: DOI.org/10.18848/18354432/CGP/v09i03/31-41.

Merriam-Webster. (n.d.). (2020), Communication. In Merriam-Webster.com dictionary. Retrieved May 26, from https://www.merriamwebster.com/dictionary/communication (Accessed 07 February2021).

Merriam-Webster. (n.d.). (2020), Competence. In Merriam-Webster.com dictionary. Retrieved August 30, from https://www.merriamwebster.com/dictionary/competency (Accessed 12 March 2021).

Merriam-Webster. (n.d.). (2020), Intercultural. In Merriam-Webster.com dictionary. Retrieved May 26, from https://www.merriamwebster.com/dictionary/intercultural (Accessed 14 March 2021).

Merriam-Webster. (n.d.). (2020), Melting pot. In Merriam-Webster.com dictionary. Retrieved August 8, from https://www.merriamwebster.com/dictionary/melting\%20pot (Accessed 09 March 2021).
Narančić-Kovać, S. and Kaltenbacher, M. (2006), Promoting intercultural awareness through literature in foreign language teacher education. In Fenner, A., Newby, D. (Eds.).Coherence of principles, cohesion of competences: exploring theories and designing materials for teacher education ( $\mathrm{p}$. 78-95). Strasbourg. Council of Europe. Retrieved from:

https://books.google.com/books?id=1e1a5EDXinM $\mathrm{C} \&$ printsec $=$ frontcover\# $\mathrm{v}=$ onepage $\& \mathrm{q} \& \mathrm{f}=$ false (Accessed 14 March 2021).

Oxford Learner's Dictionary. (n.d.). (2020), Emotional Intelligence. In oxfordlearnersdictionaries.com dictionary. Retrieved August 29, from https://www.oxfordlearnersdictionaries.com/definiti on/american_english/emotional-intelligence (Accessed 15 February2021).

Pappenheim, R. (2006), Social and cultural awareness as overruling goals in foreign language course design. In Fenner, A., Newby, D. (Eds.).Coherence of principles, cohesion of competences: exploring theories and designing materials for teacher education (p. 69-78). Strasbourg. Council of Europe. Retrieved from: https://books.google.com/books?id=1e1a5EDXinM $\mathrm{C} \&$ printsec $=$ frontcover $\# \mathrm{v}=$ onepage $\& \mathrm{q} \& \mathrm{f}=$ false (Accessed 23 March 2021).

Perry, L.B., and Southwell, L. (2011), Developing intercultural understanding and skills: models and approaches. Intercultural Education, 22(6), 453-466. DOI:10.1080/14675986.2011.644948.

Samovar, L.A., Porter, R.E., and McDaniel, E.R. (2009), Intercultural communication: A reader. Retrieved from https://books.google.com/books?hl=en \&lr=\&id=dX s5DZFCRPsC\&oi=fnd\&pg=PT325\&dq=monochro nic+and+polychronic+cultures\&ots $=61$ SPD $7 \mathrm{fEUA}$ \&sig=F_y8JYxRPz97-

$\mathrm{z} 3 \mathrm{~s} 1 \_\mathrm{R} 2 \mathrm{~d} 0 \mathrm{QDBJ} 4 \# \mathrm{v}=$ onepage $\& \mathrm{q}=$ monochronic $\% 2$ 0and\%20polychronic\%20cultures\&f=false (Accessed 23 March 2021).

Schenker, T. (2012), Intercultural Competence and Cultural Learning Through Telecollaboration. Calico Journal, 29(3). Retrieved from 10.11139/cj.29.3.449-470.

Sercu, L. (2005), Chapter 10: The future of intercultural competence in foreign language education: Recommendations for professional development, educational policy and research. In Sercu, L., Bandura, E., Castro, P., Davcheva, L., Laskaridou, C., Lundgren, U., Carmen, M.D., Garcia, M., Ryan, $\mathrm{P}$. Foreign language teachers and intercultural competence: An International investigation. (pp. 160181). United Kingdom. Multilingual Matters LTD. 
Sun, L. (2013), Culture teaching in foreign language teaching. Theory and practice in language studies, 3(2), 371-375. DOI:10.4304/tpls.3.2.371375.

Tseng, S. and Yeh, H. (2019), Fostering EFL teachers' CALL competencies through projectbased learning. Educational Technology \& Society, 22(1), p. 94-105. Retrieved from https://www.jstor.org/stable/26558831?Search=yes \&resultItemClick=true\&searchText=project+based +learning\&searchUri=\%2Faction\%2FdoBasicSearc $\mathrm{h} \% 3 \mathrm{FQuery} \% 3 \mathrm{Dproject} \% 2 \mathrm{Bbased} \% 2 \mathrm{Blearning} \& \mathrm{a}$ b_segments $=0 \% 2$ Fbasic_SYC-5187_SYC-

$5188 \% 2$ F5188\&refreqid=fastly-

default $\% 3 \mathrm{~A} 38 \mathrm{~b} 9 \mathrm{a} 510 \mathrm{fe} 522 \mathrm{a} 0 \mathrm{c} 60 \mathrm{ebe} 9 \mathrm{~b} 278 \mathrm{a} 473 \mathrm{af} \& \mathrm{se}$ q=1\#metadata_info_tab_contents (Accessed 14 February 2021).

Xu, Z. (2017), Developing metacultural writing competence for online intercultural communication: Implications for English language teaching. The electronic journal for English as a second language, 20(4). Retrieved from: https://files.eric.ed.gov/fulltext/EJ1137966.pdf (Accessed 14 February 2021).

Yusof, N., Cheah Lynn-Sze, J. and Kaur, A. (2019), Post graduate students' insights into understanding intercultural communication in global workplaces. Innovations in Education \& Teaching International, 56(1), 77-87. Retrieved from https://doi.org/10.1080/14703297.2017.1417148.
Wikipedia contributors. (2018), Bennett scale. In Wikipedia, The Free Encyclopedia. Retrieved 22:19, May 29, 2020, from https://en.wikipedia.org/w/index.php?title=Bennett scale\&oldid $=860852858$ (Accessed 12 March 2021).

Wikipedia contributors. (2020), Demographics of Kosovo. In Wikipedia, The Free Encyclopedia. Retrieved 15:34, August 28, 2020, from https://en.wikipedia.org/w/index.php?title=Demogr aphics_of_Kosovo\&oldid=975402719. (Accessed 12 March 2021).

Информация о конфликте интересов: автор не имеет конфликта интересов для декларации. Conflicts of Interest: The author has no conflict of interests to declare.

About the author:

Fisnike Pllana, English Teacher, MA in International Communications, Faculty of Languages, Cultures and Communication, South-Eastern European University, Republic of Northern Macedonia, Skopje.

\section{Данные автора:}

Фиснике Пллана, преподаватель английского языка, магистрант международных коммуникаций, факультет языков, культур и коммуникации, Юго-Восточноевропейский университет, Республика Северная Македония, Скопье. 